DOI https://doi.org/10.30929/2307-9770.2019.07.02.06

UDC 37.091.113:[001.895:008](1-87)

\title{
Development of innovative culture of the head of educational establishment: foreign experience analysis
}

\author{
Kozlov D.* \\ Sumy State Pedagogical University named after AS Makarenko, Sumy, Ukraine
}

Received: $18.03 .2019 \quad$ Accepted: 14.04.2019

\begin{abstract}
The foreign researchers' views on the formation and development problem of the head's innovative culture of the educational institution are analyzed in the article. The creative process stages (preparatory, incubation, enlightenment, executive), the implementation of which ensures conditions creation for innovative development and activation of innovative processes, functional resposibilities definition and distribution, is based on the complex research methods use - systematization, generalization, classification, comparison - the structure definition of the innovative solutions adoption, the partnership space creation, networks and resources in the educational establishment. Information is provided on key tools and methods for ensuring a systematic approach to innovation management at an educational establishment (brainstorming method, the search for creative ideas through collective ideas exchange, non-standard thinking, the theory of solving inventive tasks, SCAMPER creativity technique, associative maps, cascading arrangement of spontaneous ideas, knowledge tree, parametric analysis, semantic processes, problem abstract presentation, ideas book, analogy, evaluation). It is stated that the head of the educational establishment is a key figure in shaping the establishment innovative culture. This manager's activity directions are described, in particular, the international staff attraction, the preservation of high-qualified student contingent, support to the educational establishment staff in the process of introducing innovations, personnel training for the development of creativity provision and innovations introduction, the establishment of appropriate evaluation systems and encouragement provided the innovative initiative, establishing cooperation with similar profile educational establishment, and carrying out activities aimed at obtaining international recognition as a result of innovative research approach application, the pilot programs implementation, innovations protection and commercialization. The head's activities types of the educational establishment with innovation culture high level are singled out. The manager's qualification standards, who is the innovation culture bearer ("Standards of education of managers' of educational establishment of the interpersonal consortium", "Professional standards for managers in educational branch") are characterized. Innovative programs for the training of heads of educational establishments based on the introduction of national standards in the USA are considered, which include university programs, district programs, third-party professional development programs and affiliate programs.
\end{abstract}

Key words: innovation, innovative culture, educational institution, head of educational institution, training program, standard of professionalism of the head of educational institution.

\section{Розвиток інноваційної культури керівника закладу освіти: аналіз зарубіжного досвіду}

\author{
Козлов Д. 0.
}

Сумський державний педагогічний університет імені А. С. Макаренка, Суми, Україна

\begin{abstract}
Анотація. У статті розглянуто погляди зарубіжних дослідників на проблему формування та розвитку інноваційної культури керівника закладу освіти. На основі використання комплексу методів дослідження систематизації, узагальнення, класифікації, порівняння - виокремлено етапи креативного процесу (підготовчий, інкубаційний, прозріння та просвітлення, виконавчий), реалізація яких забезпечує створення умов для інноваційного розвитку та активізації інноваційних процесів, визначення та розподілу функціональних обов'язків, визначення структури прийняття інноваційних рішень, створення простору партнерства, мереж та ресурсів у закладі освіти. Подано інформацію про ключові інструменти та методи для
\end{abstract}

\footnotetext{
Corresponding Author: Kozlov Dmytro Oleksandrovych. Phone: 095-61-097-28. E-mail: 32012anna@gmail.com Sumy State Pedagogical University named after A. S. Makarenko,

St. Romenskaya, 87, Sumy, Ukraine, 40002.

Biдnовідальний автор: Козлов Дмитро Олександрович. Тел. 095-61-097-28. E-mail: 32012anna@gmail.com Сумський державний педагогічний університет імені А. С. Макаренка, вул. Роменська, 87, м. Суми, Україна, 40002.
} 
забезпечення системного підходу до управління інноваціями в закладі освіти (метод мозкової атаки, пошук творчих ідей шляхом колективного обміну ідеями, нестандартне мислення, теорія вирішення винахідницьких завдань, методика креативності SCAMPER, асоціативні карти, каскадне розташування спонтанних ідей, дерево пізнання, параметричний аналіз, семантичні процеси та абстрактне представлення проблеми, книга ідей, аналогії, оцінювання). Відстоюється думка про те, що керівник закладу є ключовою фігурою у формуванні інноваційної культури закладу освіти. Охарактеризовано напрями діяльності такого керівника, зокрема, залучення міжнародних співробітників, збереження якісного учнівського контингенту, надання підтримки співробітникам закладу освіти у процесі впровадження інновацій, забезпечення підготовки персоналу закладу задля розвитку рівня креативності та впровадження інновацій, створення належних систем оцінювання та заохочування за умови прояву інноваційної ініціативи, налагодження співпраці з закладами освіти подібного профілю, здійснення діяльності, спрямованої на отримання закладом освіти визнання на міжнародному рівні у результаті застосування інноваційного підходу до проведення досліджень, впровадження експериментальних програм, забезпечення захисту і комерціалізації інновацій. Виокремлено види діяльності керівника закладу освіти, що володіє високим рівнем інноваційної культури. Схарактеризовано стандарти кваліфікації керівника, що є носієм інноваційної культури («Стандарти освіти керівників освітніх установ міжштатного консорціуму»; «Професійні стандарти для керівників у галузі освіти»). Розглянуто інноваційні програми підготовки керівників закладу освіти США на основі запровадження національних стандартів, які включають університетські програми, окружні програми, програми сторонніх організацій підвищення професійної кваліфікації та партнерські програми.

Ключові слова: інновація, інноваційна культура, заклад освіти, керівник закладу освіти, програма підготовки, стандарт професіоналізму керівника закладу освіти.

\title{
Развитие инновационной культуры руководителя учреждения образования: анализ зарубежного опыта
}

\author{
Козлов Д. А. \\ Сумской государственный педагогический университет имени А. С. Макаренко, Сумы, Украина
}

\begin{abstract}
Аннотация. В статье рассмотрены взгляды зарубежных исследователей на проблему формирования и развития инновационной культуры руководителя учебного заведения. На основе использования комплекса методов исследования - систематизации, обобщении, классификации, сравнения - выделены этапы креативного процесса (подготовительный, инкубационный, прозрение и просветление, исполнительный), реализация которых обеспечивает создание условий для инновационного развития и активизации инновационных процессов, определения и распределения функциональных обязанностей, определения структуры принятия инновационных решений, создания пространства партнерства, сетей и ресурсов в учебном заведении. Представлена информация о ключевых инструментах и методах для обеспечения системного подхода к управлению инновациями в учебном заведении (метод мозговой атаки, поиск творческих идей путем коллективного обмена идеями, нестандартное мышление, теория решения изобретательских задач, методика креативности SCAMPER, ассоциативные карты, каскадное расположение спонтанных идей, дерево познания, параметрический анализ, семантические процессы, и абстрактное представление проблемы, книга идей, аналогии, оценка). Отстаивается мысль о том, что руководитель учебного заведения является ключевой фигурой в формировании инновационной культуры заведения. Проанализированы направления деятельности такого руководителя, в частности, привлечение международных сотрудников, сохранение качественного ученического контингента, оказание поддержки сотрудникам учебного заведения в процессе внедрения инноваций, обеспечение подготовки персонала заведения для развития уровня креативности и внедрение инноваций, создание надлежащих систем оценки и поощрение при условии проявления инновационной инициативы, налаживание сотрудничества с учебными заведениями подобного профиля, осуществление деятельности, направленной на получение учебным заведением признания на международном уровне в результате применения инновационного подхода к проведению исследований, внедрение экспериментальных программ, обеспечение защиты и коммерциализации инноваций. Выделены виды деятельности руководителя учреждения образования, обладающего высоким уровнем инновационной культуры. Охарактеризованы стандарты квалификации руководителя, который является носителем инновационной культуры («Стандарты образования руководителей образовательных учреждений межштатных консорциумов», «Профессиональные стандарты для руководителей в области образования»). Рассмотрены инновационные программы подготовки руководителей учебного заведения США на основе внедрения национальных стандартов, которые включают университетские программы, окружные программы, приложения сторонних организаций повышения профессиональной квалификации и партнерские программы.
\end{abstract}

Ключевые слова: инновация, инновационная культура, учебное заведение, руководитель учебного заведения, программа подготовки, стандарт профессионализма руководителя учреждения образования. 


\section{Bcmyn}

Інтеграція України до світового економічного простору, вимоги неперервного підвищення кваліфікації та розвиток фахівця співпадають сьогодні 3 формуванням у розвинутих країнах інноваційного суспільства, основою якого $€$ особистість, що володіє високим рівнем інноваційної культури. Розвиток вищої освіти в Україні в означеному контексті потребує посиленої уваги суспільства до підготовки керівника закладу освіти інноваційного спрямування, який забезпечує ефективність управління задля досягнення очікуваного результату. Реалізація означеного стратегічного завдання потребує модернізації освітнього процесу, використання інноваційних програм та технологій, що знайшло відображення у Законах України «Про вищу освіту» (2014), «Про освіту» (2017), Національної стратегії розвитку освіти в Україні на період до 2021 року (2013), Концепції «Нова українська школа» (2016).

Викликають інтерес здобутки високорозвинутих країн у частині підготовки керівника закладу освіти, формування та розвитку його інноваційної культури. Важливим є аналіз зарубіжного досвіду, який дозволяє з'ясувати особливості процесу стандартизації професійної готовності керівника закладу освіти до реалізації інновацій, забезпечення ефективності інноваційних процесів у системі управління закладом освіти.

Метою статmі є з'ясування інноваційних зарубіжних ідей задля розвитку інноваційної культури вітчизняних керівників закладів освіти в системі вищої педагогічної освіти.

\section{II Матеріали і методи дослідження}

У процесі вивчення піднятої проблеми використано комплекс методів, а саме: загальнонаукові (аналіз, синтез, узагальнення, порівняння, конкретизація, абстрагування - для з'ясування особливостей інтерпретації обраної проблеми в наукових джерелах); конкретнонаукові (термінологічний аналіз - для визначення поняттєво-категоріального апарату розгляду проблеми дослідження, логічний аналіз - для класифікації та структуризації джерельної бази, типологічний метод - для здійснення типологізації підходів до формування та розвитку інноваційної культури керівника закладу освіти у зарубіжних наукових розвідках, метод екстраполяції - для актуалізації позитивного зарубіжного досвіду в сучасних умовах реформування вітчизняної системи вищої педагогічної освіти).

У вивченні зазначеної проблеми спиралися на системний підхід, який уможливив розкриття взаємозв'язків та взаємовпливів у структурі освітнього зарубіжного процесу та виокремленні головного і суттєвого у вибудові категоріального поля дослідження.

Синергетичний підхід створив підґрунтя для пізнання принципів самоорганізації зарубіжних систем розвитку інноваційної культури керівника закладу освіти.

Цивілізаційний підхід уможливив розгляд досліджуваного феномену як нелінійного процесу у структурі формування світоглядних засад розвитку менеджменту освіти.

\section{III Результати}

Інноваційна культура керівника визначається як процес створення умов для інноваційного розвитку та активізації інноваційних процесів, визначення та розподілу функціональних обов'язків, визначення структури прийняття інноваційних рішень, створення фізичного простору, партнерства, мереж та ресурсів, що підтримують інноваційну діяльність та інноваційне мислення [11, с. 41]. Д. Аджей визначив інноваційну культуру керівника як синтез різних стилів керівництва в установі з метою здійснення впливу на співробітників задля продукування креативних ідей, створення інноваційний продуктів, надання інноваційних послуг та прийняття інноваційних рішень [1, с. 103].

Досвід інноваційної поведінки керівника має практичну значимість. Існує зв'язок між інноваційним рольовим моделюванням і генерацією ідей. На думку науковців К. Джауссі та С. Діонне, керівники, які діють креативно, надихають та спонукають своїх підлеглих до творчої активності та креативності [8]. Наприклад, згідно дослідженням К. Шеллі та Дж. Перрі-Сміта, співробітникам, яким були надані зразки творчих розробок, вдалося дослідити елементи креативності і, у свою чергу, продемонструвати більш креативну власну поведінку [13]. Крім того, Дж. Сандбо дійшов висновку, що керівник «підприємницького типу» позитивно впливає на інноваційну діяльність підлеглих [15]. 
Керівник нового типу, який є носієм інноваційною культури, повинен розуміти чотири ключові етапи креативного процесу:

1. Підготовчий: це етап, на якому креативна людина або команда визнає фракт наявності проблеми та намагається вникнути в її суть. Він характеризується збором інформації і передбачає розподіл обов'язків, формування зон особистої зацікавленості і координацію дій.

2. Інкубаційний: на цьому етапі основна проблема може бути відсунута на другий план і навіть забута, але розумова діяльність не припиняється. В процесі вирішення якого-небудь розумового завдання основний акцент робиться не на послідовному логічному зв'язку суджень, а на міркуваннях та нових, оригінальних ідеях.

3. Eman прозріння або просвітлення: на цьому етапі ідеї щодо інновацій можуть з'явитися несподівано. Як правило, це відбувається, коли члени колективу, який працює над креативним проектом або виконує науково-творчу роботу, збираються разом після деякого періоду часу. Спонтанний обмін інформацією може призвести до продукування ідей, які жоден з учасників не міг би сформулювати самостійно.

4. Виконавчий етап: це етап, який відокремлює креативність від успішного впровадження інновацій. Нові ідеї вимагають рішучих дій, цілеспрямованості і можливості створення коаліцій в цілях внесення змін. У зв'язку з тим, що виконавчий етап вимагає застосування більше соціальних навичок, ніж технічної майстерності, в результаті якої відбувається генерація інноваційних ідей, на цьому етапі дієвим є організаційний менеджмент, що найбільш активно допомагає в просуванні креативності [5, с. 96-97].

Для розвитку інноваційної культури організації керівник закладу повинен не лише розуміти етапи креативного процесу, але й впроваджувати ефективну практику таких сладових:

1. Вибрати найбільш перспективних співробітників-новаторів («чемпіонам інновацій»): щоб створити «розсадник інноваційних ідей» в організації, керівник повинен відібрати найбільш перспективних генераторів ідей і надати їм додаткові ресурси. Керівник повинен забезпечити розуміння такими співробітниками етапів реалізації креативного процесу.

2. Створити «буфрерні зони» для найбільш інноваційного персоналу, тобто якийсь захисний кокон навколо креативних співробітників або інноваційних команд в організації з метою не перешкоджати збору інформації, що відбувається на підготовчому етапі креативного процесу. Важливим $\epsilon$ забезпечення персоналу, задіяного в креативному процесі, інструментами та ресурсами у процесі пошуку інфрормації або відповідей на запитання.

3. Надати «чемпіонам інновацій» широку свободу дій. Важливим на цьому етапі $є$ те, що керівникові слід утриматися від критики й засудження їх дій або методик.

4. Не вимагати негайного вирішення проблем чи миттєво негайного отримання результатів: будьяка команда може приймати рішення або надавати рекомендації поетапно. Суворе дотримання строків може негативно вплинути на реалізацію креативного процесу.

5. Забезпечити підтримку інноваційних рішень та креативних ідей від етапу їх створення до етапу реалізації. Керівник повинен відбирати кращі ідеї та рішення, спрямовувати їхнє подальше розроблення і сприяти успішному втіленню в життя таких ідей та рішень [5, с. 98-99]

Згідно з дослідженнями науковців Т. Амабіля, К. Суллівана та Г. Харпера [14] з'ясовано, що для підвищення креативності як керівника, так і підлеглих, необхідними є три складові:

- спеціальні знання та навички (технічні, процедурні та загальні знання),

- креативне мислення (наскільки творчо особистість підходить до проблеми та наскільки гнучким мисленням вона володіє у процесі її вирішення),

- мотивація (особливо внутрішня мотивація) [9, с. 45].

Науковці Д. Хорс і Дж. Вехар стверджують, що інноваційна культура керівника ґрунтується на трьох компонентах:

1) набір інструментів (прототипування, метод мозкової атаки, асоціативні карти, творчий принцип бісоціації): набір інструментів і методів, що використовуються для створення нових можливостей, їх реалізації в межах організації, визначення напряму інноваційної діяльності, розподілу обов'язків; 
2) набір умінь, навичок та компетениій: основа, яка дозволяє інноваційному керівникові використовувати знання і здібності для досягнення своїх цілей;

3) спосіб мислення, ставлення та поведінка (зацікавленість та допитливість, розгляд проблеми з різних точок зору, толерантність до невизначеності, прийняття позитивних рішень): становлення та поведінка, що дають можливість ефективно використовувати набір інструментів, умінь, навичок та компетенцій [6, с. 10].

Керівником закладу освіти можуть бути застосовані ключові інструменти та методи для забезпечення системного підходу до управління інноваціями, зокрема розвитку креативного мислення: метод мозкової атаки, пошук творчих ідей - знаходження рішення проблем шляхом колективного обміну ідеями; нестандартне мислення; теорія вирішення винахідницьких завдань; методика креативності SCAMPER; асоціативні карти; система карток із самоклеючого паперу; фіксування всіх спонтанних ідей (наприклад, каскадне розташування); древо пізнання (значення); параметричний аналіз; семантичні процеси - матриця випадкових величин та матриця пошуку ідей; абстрактне представлення проблеми; книга ідей; аналогії; оцінювання тощо [7, с. 34].

Науковцем Т. Роскорлом запропоновано такі компоненти інноваційної культури керівника:

1. Прийняття викликів та складних завдань, що вимагають максимальних зусиль

Керівник, який $є$ носієм інноваційної культури, не делегує креативну та інноваційну діяльність, а здійснює управління нею. Він намагається створити культуру критичного й творчого мислення, що приймає виклики.

2. Управління процесом змін за допомогою організації колективної творчої діяльності та розширення можливостей застосування колективних знань та досвіду

Інноваційний керівник застосовує творчий підхід, підтримує ініціативність і намагається підтримувати викладацький та учнівський склад і заохочувати їх до реалізації передачі знань та обміну досвідом.

\section{3. Формування культури закладу}

Інноваційний керівник створює культуру ризику, змін, критичного і креативного мислення. Він розвиває вміння самостійно і творчо мислити та застосовувати здобуті знання в управлінській практиці, а не намагається суворо і неухильно дотримуватися правил. Керівник, який є носієм інноваційної культури, переходить від правил до принципів, створює всередині закладу освіти клімат та середовище, що стимулюють пошук і освоєння нових перспективних ідей, і не виступає проти порушення усталених норм та правил, якщо вони більше не є доцільними.

4. Створення системи профресійного навчання

Інноваційний керівник створює професійні навчальні спільноти у закладі освіти. Ефективне професійне навчання має певні характеристики: триває протягом тривалого періоду або носить безперервний характер, має предметно-орієнтований характер, вбудоване в професійні освітні спільноти, орієнтоване на вирішення конкретних задач у сфері навчання, оцінки, спостереження і ресрлексії.

5. Прийняття рішень і систематизація

Керівник, який є носієм інноваційної культури, створює базу для визначення місії й цілей, вироблення стратегії закладу, приймає рішення щодо забезпечення ресурсами, стимулювання профресійного розвитку.

6. Забезпечення доступу до інформаційно-комунікаційної інфрраструктури та цифрових технологій

Інноваційний керівник забезпечує комп'ютерну та інформаційну грамотність викладацького та учнівського складу, намагається забезпечити заклад освіти комп'ютерними комплексами та мультимедійним обладнанням, надає можливість отримувати доступ до електронних навчальних ресурсів мережі Інтернет.

\section{7. Вимога підзвітності}

Інноваційний керівник делегує відповідальність, але вимагає підзвітності від підлеглих. На початку інноваційної діяльності він не повинен бути занадто вимогливим до співробітників, щоб вони почувалися комфортно, не боялися ризикувати та понести покарання у разі поразок або невдач, навчалися на власному досвіді [12]. 
Керівник закладу освіти $є$ ключовою фігурою у формуванні інноваційної культури закладу. I $є$ відкритим до сприйняття нових ідей, підтримує інновації і сприяє впровадженню інноваційних процесів. Зауважимо, що напрями діяльності керівника закладу освіти з інноваційною культурою включають в себе:

- залучення міжнародних співробітників, формування та збереження якісного учнівського контингенту;

- надання підтримки співробітникам закладу освіти процесі впровадження інновацій;

- розширення можливостей і підвищення рівня участі учнів і викладацького складу в процесі прийняття рішень;

- забезпечення підготовки персоналу (за допомогою розробки та реалізації академічних програм) з метою розвитку рівня креативності та впровадження інновацій;

- формування креативності як вимоги навчальних програм і функціональних обов'язків персоналу;

- створення належних систем оцінювання та заохочення за умови прояву інноваційної ініціативи;

- стимулювання припливу інвестицій у наукові дослідження і розробки;

- налагодження співпраці з закладами освіти подібного профілю та з закладами вищої освіти на глобальному рівні;

- налагодження співпраці з промисловістю в рамках науково-дослідних проектів та інноваційних ініціатив;

- здійснення діяльності, спрямованої на отримання закладом освіти визнання на міжнародному рівні у результаті застосування інноваційного підходу до проведення досліджень, впровадження експериментальних навчальних програм, забезпечення освітнього середовища, а також швидкої адаптації випускників закладу на ринку праці;

- впровадження цифрових та інформаційних технологій в усі процеси, пов'язані з освітою, дослідженнями, посередництвом, комунікаціями та управлінням;

- забезпечення захисту і комерціалізації інновацій [7, с. 19].

У контексті піднятої проблеми важливим є аналіз зарубіжного досвіду, який дозволяє з'ясувати особливості процесу формування та розвитку інноваційної культури закладу освіти. Схарактеризуємо програми підготовки керівника закладу освіти.

У рамках формування інноваційної культури керівник закладу освіти повинен:

- Переглядати та корегувати навчальні програми, їх структуру, зміст та процес реалізації з метою відкриття нових напрямів підготовки, запровадження нових режимів навчання.

- Залучати викладацький склад та дослідників 3 метою створення неоднорідного штату співробітників, навички, підготовка та досвід яких будуть взаємодоповнювати і сприяти розвитку інноваційних ініціатив.

- Оцінювати діяльність науково-дослідного колективу, розширювати його склад, а також приймати організаційні рішення з метою підтримки дослідно-експериментальної та інноваційної діяльності.

- Забезпечувати науково-дослідні групи та окремих дослідників належними умовами для успішної розробки та реалізації програм, проектів і оприлюднення результатів наукової діяльності у вигляді різних видів публікацій.

- Підвищувати рівень довіри до співробітників та учнів шляхом залучення їх до інноваційної діяльності та процесу перетворень у закладі освіти, а також надавати інноваційному персоналу більший обсяг повноважень та розширювати сферу його автономії.

- Застосовувати систему стимулів та винагород, реалізовувати програму підтримки для учнівського та викладацького складу, науково-дослідного колективу, які здатні мислити нестандартно, задіяні в інноваційних проектах (у співробітництві з внутрішніми та зовнішніми сторонами) і виступають 3 низкою підприємницьких ініціатив.

- Заохочувати інноваційних співробітників і учнів, надаючи підтримку, враховуючи їх інтереси, виявляючи толерантність у разі виникнення проблем та стимулюючи корпоративну креативність (заклад освіти розглядається як фабрика інноваційних ідей).

- Забезпечувати комплексну підготовку та розвиток персоналу. 
- Забезпечити інтегрування таких елементів, як дослідницькі навички, критичне мислення, креативність, інновації та підприємництво у процес викладання всіх дисциплін.

- Сприяти взаємодії з партнерами, які готові до співпраці щодо реалізації навчальних програм та проведенню наукових досліджень, у тому числі з освітніми установами, приватними підприємствами, державними структурами, регіональними і місцевими органами влади та іншими державними структурами, що мають намір брати участь у реалізації експериментальних та інноваційних ініціатив 3 метою пошуку нових підходів.

- Сприяти створенню нових платформ, в тому числі цифрових соціальних мереж, внутрішніх комунікацій з учнями (забезпечення інформацією про навчальну діяльність, завдання, проекти, доступу до Інтернету, пошти, форумів, СМС-повідомлень), а також передачу на перевірку зроблених завдань і отримання зворотнього зв'язку з використанням цифрових технологій.

- Сприяти використанню інформаційних технологій та впровадженню навчання з використанням електронних технологій з метою обміну знаннями між закладом освіти та приватним сектором.

- Забезпечувати захист інновацій, зокрема, за допомогою патентних бюро.

- Зміцнювати зв'язки між промисловістю і закладом освіти для спільної роботи в науководослідних проектах та реалізації інноваційних ініціатив.

- Надавати підтримку інноваційному персоналу закладу та учням.

- Розробляти плани фінансування та надавати поради стосовно можливості отримання фінансування на проведення досліджень та реалізацію інноваційних ініціатив.

- Формувати сприятливе середовище для інноваційної діяльності (у рамках стратегії) з метою зміцнення впевненості співробітників і учнів у своєму інноваційному потенціалі.

- Призначити заступника директора 3 інновацій та трансфреру технологій для підтримки інноваційної діяльності начальної установи.

- Розробляти на організаційному та індивідуальному рівнях систему стратегічних документів 3 урахуванням орієнтовних кількісних показників науково-дослідницької, інноваційної і підприємницької діяльності, що є основою для створення середовища, що стимулює розвиток креативності та інновацій.

- Забезпечити правовий режим в рамках закладу освіти 3 метою сприяння розвитку співробітництва, партнерських відносин у сфері промисловості та розширення доступу до наукових ресурсів [7, с. 25, 30-31].

Розвиток інноваційної системи шкільної освіти зумовив потребу у розробленні стандартів кваліфрікації та програм підготовки керівника закладу освіти, що є носієм інноваційної культури.

Зокрема, у США у середині 1990-х років було створено Міжштатний консорціум із ліцензування керівників шкіл (The Interstate School Leaders Licensure Consortium - ISLLC) $з$ метою розроблення національних стандартів для керівників у галузі освіти, а саме «Стандартів освіти керівників освітніх установ міжштатного консорціуму» (Interstate School leaders Licensure Consortium Standards for School Leaders) (1996р.). У 2008 році вищезазначені Стандарти було переглянуто і змінено:

Стандарт 1: Керівник закладу освіти сприяє підвищенню рівня академічної успішності кожного учня, стимулюючи розвиток, визначаючи напрями реалізації стратегії та спільного бачення перспектив розвитку навчального процесу, що підтримується усіма зацікавленими сторонами.

Стандарт 2: Керівник закладу освіти сприяє підвищенню рівня академічної успішності кожного учня шляхом створення та підтримки організаційної культуру і запровадження оновлених програм, спрямованих на забезпечення учнівського складу якісними освітніми послугами та на професійне зростання викладацького складу.

Cтандарт 3: Керівник освітнього закладу сприяє підвищенню рівня академічної успішності кожного учня, здійснюючи управління організаційним та навчальним процесами, а також ресурсами для забезпечення безпечного та ефективного освітнього середовища.

Cтандарт 4: Керівник закладу освіти сприяє підвищенню рівня академічної успішності кожного учня, співпрацюючи з викладачами та членами спільноти, задовольняючи освітні потреби та враховуючи інтереси зацікавлених сторін, а також мобілізуючи ресурси спільноти.

Стандарт 5: Керівник закладу освіти сприяє підвищенню рівня академічної успішності кожного учня, керуючись високими етичними принципами, а також принципами чесності та професіоналізму. 
Cтандарт 6: Керівник закладу освіти сприяє підвищенню рівня академічної успішності кожного учня, розуміючи та враховуючи політичні, соціальні, економічні, правові і культурні умови функціонування начального закладу [3, с. 14-15].

У 2015 році в США було розроблено «Профресійні стандарти для керівників у галузі освіти» (Professional Standards for Educational Leaders), які складаються з 10 стандартів:

Стандарт 1. Місія, бачення та основні цінності.

Ефективні керівники закладу освіти сприяють реалізації спільного бачення, місії та основних цінностей якісної освіти, а також забезпечують підвищення рівня академічної успішності та благополуччя кожного учня.

Стандарт 2. Професійно-етичні норми і принципи

Ефективні керівники закладу освіти діють у відповідності з етичними та професійними нормами і принципами у процесі забезпечення академічної успішності та благополуччя кожного учня.

Стандарт 3. Рівний та справедливий доступ до якісної освіти

Ефективні керівники закладу освіти намагаються надавати всім учням можливість доступу до якісної освіти.

Стандарт 4. Навчальний план, навчальний процес, система оцінювання

Ефективні керівники закладу освіти забезпечують реалізацію навчального процесу належною мірою та створюють систему оцінювання, щоб сприяти підвищенню рівня академічної успішності та благополуччя кожного учня.

Стандарт 5. Надання допомоги і підтримки учасникам освітнього процесу

Ефективні керівники закладу освіти створюють сприятливе шкільне середовище з метою підвищення рівня академічної успішності та благополуччя кожного учня.

Стандарт 6. Профресійна компетентність персоналу школи

Ефективні керівники закладу освіти забезпечують розвиток професійного потенціалу викладацького складу з метою підвищення рівня академічної успішності та благополуччя кожного учня.

Стандарт 7. Забезпечення сприятливої робочої атмосфрери для вчителів та інших співробітників

Ефективні керівники закладу освіти забезпечують належні умови праці та сприятливу робочу атмосферу для викладачів та інших співробітників з метою підвищення рівня академічної успішності та благополуччя кожного учня.

Стандарт 8. Залучення членів сім'ї та спільноти.

Ефективні керівники закладу освіти намагаються повною мірою залучати членів сім'ї та спільноти до проблем школи та налагодити їх плідну співпрацю з метою підвищення рівня академічної успішності та благополуччя кожного учня.

Стандарт 9. Керівництво та управління

Ефективні керівники закладу освіти здійснюють управління господарською, навчальною та виховною діяльністю, а також ресурсами навчального закладу з метою підвищення рівня академічної успішності та благополуччя кожного учня.

Стандарт 10. Поліпшення роботи школи

Ефективні керівники закладу освіти забезпечують безперервне вдосконалення та залучення у цей процес усіх учасників освітнього процесу [10].

Отже, система підготовки керівників закладів освіти $є$ складним, багатофракторним явищем. Зокрема, в США окремі штати встановлюють вимоги до ліцензування та атестації керівників закладів освіти, а більшість штатів затвердили програму підготовки керівників шкіл на основі магістерських програм. Інноваційні програми підготовки керівників навчального закладу розробляються на основі запроваджених національних стандартів. Зокрема, у США існують чотири типи програм, а саме:

- університетські програми - впроваджуються закладом вищої освіти для отримання ступеня магістра керівника закладу освіти та передбачають ліцензування керівників на додаток до здобуття ступеня магістра в акредитованому навчальному закладі;

- окружні програми (в масштабі округу) - розробляються та реалізуються шкільними округами, а також можуть передбачати співпрацю з сторонніми організаціями підвищення профресійної кваліфікації; 
- програми сторонніх організацій підвищення професійної кваліфікації - некомерційних організацій, наприклад, «Мережа стажування керівників шкіл» (PRN), «Нові лідери для нових шкіл» (NLNS), Фонд Уолліса (Wallace Foundation); державні альтернативні атестаційні програми;

- партнерські програми, що реалізуються спільними зусиллями університетів, округів та/або сторонніх організацій $[4 ; 2$, с. 17$]$.

Інноваційні програми підготовки керівників закладів освіти мають наступні характеристики:

1) чітка спрямованість на процес керівництва, організації та здійсненні освітнього процесу у відповідності зі змістом програми;

2) розроблення навчальних програм на основі національних стандартів, фокусуючись на основах керівництва процесом навчання, організаційному менеджменті та управлінні змінами;

3) стажування у школах з досвідченим керівництвом;

4) створення когерентних груп для спільної роботи в практично орієнтованих ситуаціях;

5) реалізація освітніх стратегій, що поєднують теорію і практику, наприклад, проблемноорієнтоване навчання;

6) ретельний відбір кандидатів і викладацького складу;

7) міцні партнерські стосунки зі шкільними закладами з метою забезпечення належного стажування [4].

\section{IV Обговорення}

Студіювання наукових досліджень зарубіжних учених засвідчує, що актуальність дослідження процесу формування та розвитку інноваційної культури керівника закладу освіти зумовлено інноваційними змінами в суспільстві та об'єктивними його потребами у професіоналах, які ефективно використовують інновації у власній професійній діяльності. Так, за останні десятиліття з'явилися наукові розвідки, що розкривають основні компоненти інновацій вищої школи у рамках мережі інноваційних шкіл (Д. Уотт). К. Поллоком розкрито проблеми інновацій у початковій школі, а також у співавторстві 3 К. Дібболом досліджено характер заміни та інновацій в інноваційних школах. Б. Дженьюнайте присвятила праці проблемі інноваційної культури вчителя. Науковцем Т. Роскорлом визначено основні етапи становлення інноваційного керівника [12].

К. Джауссі та С.Діонне виокремили зв'язок між інноваційним рольовим моделюванням та генерацією ідей [8].

Дослідник Дж. Сандбо відстоює думку про те, що керівник підприємницького типу позитивно впливає на інноваційну діяльність підлеглих [15].

Дослідники Т. Амабіль, К. Сулліван та Г. Харпер зясували, що для підвищення креативності як керівника, так і підлеглих необхідними є спеціальні знання та навички (технічні, процесуальні, загальні знання), креативне мислення (творчий підхід особистості до вирішення проблеми та вияв гнучкості мислення особистості у процесі її вирішення) та мотивація [14].

Науковці Д. Хорс та Дж. Вехар доводять, що інноваційна культура керівника включає: набір інструментів і методів, що використовуються для створення нових можливостей в організації; набір умінь, навичок та компетенцій; спосіб мислення, ставлення та поведінка [6].

Заначимо, що дана стаття присвячена проблемі професійної підготовки сучасного керівника закладу освіти. Тому викликає інтерес система підготовки керівників закладів освіти у високорозвинутих країнах, зокрема США. З'ясовано, що в США окремі штати встановлюють вимоги до підвищення та атестації керівників закладів освіти. Більшість штатів ініціюють підготовку керівників закладів освіти на основі магістерських програм.

Подано характеристику професійних стандартів для керівників у галузі освіти, що є носієм інноваційної культури.

\section{V Висновки}

Таким чином, студіювання наукових праць зарубіжних учених дозволили з'ясувати інноваційні ідеї задля розвитку інноваційної культури вітчизняних керівників закладів освіти в системі вищої педагогічної освіти. Констатовано, що реалізація креативного процесу забезпечує інноваційний розвиток та 
активізацію інноваційних процесів у закладі освіти. Конкретизовано напрями діяльності керівника закладу освіти, які забезпечують умови для реалізації інноваційних процесів, ефективного розподілу функціональних обов'язків, визначення ефективної структури прийняття інноваційних управлінських рішень, налагодження партнерства та підтримки інноваційних освітніх мереж. Подано матеріал щодо освітніх програм та професійних стандартів для керівників у галузі освіти.

Проведене дослідження не вичерпує всіх аспектів розвитку інноваційної культури керівника закладу освіти. Враховуючи широкий вектор дослідження означеного феномену, перспективними $€$ вивчення технологій розвитку інноваційної культури майбутнього керівника закладу освіти у процесі магістерської підготовки в університетах США.

\section{Бібліографрічні посилання}

[1] Adjei D. (2013). Innovation Leadership Management. International Journal of ICT and Management. 1(2). 103-106.

[2] Adkins E. The Effectiveness of Principal Preparation Program Type for Administrative Work. Theses, Dissertations and Capstones. Paper 4. - 2009. URL:http://mds.marshall.edu/etd/4/

[3] Council of Chief State School Officers. Educational Leadership Policy Standards: ISLLC Washington, 2008 http://www.ccsso.org/Documents/2008/educational_Leadership_Policy_Standards_2008.pdf

[4] Davis S., Darling-Hammond L., LaPointe M., \& Meyerson D. (2005). School Leadership Study Developing Successful Principals. Stanford : Stanford Educational Leadership Institute.

[5] Gangwar S., Padmaja K .V. (2012). Building a Culture of Creativity and Practice of Innovation. HRD Practices in Contemporary Industries. Global Vision Publishing House. P. 93-102.

[6] Horth D. M., Vehar J. (2012). Becoming a Leader Who Fosters Innovation. Center for Creative Leadership. URL: http://www.ccl.org/wp-content/uploads/2014/03/BecomingLeaderFostersInnovation.pdf

[7] Integration of an Innovation Culture as Part of the Institutional Strategy: Strategic Guide for Higher Education Institutions. URL: http://www.medinnoall.eu/sites/medinnoall.eu/files/English.pdf.

[8] Jaussi K.S. and Dionne S.D. (2003). Leading for creativity: the role of unconventional leader behavior, Leadership Quarterly. 14. 4-5. PP. 475-98.

[9] Likar B., Fatur P., Mrgole U. (2013). Innovation management. 1 st. ed. Ljubljana: Korona plus - Institute for Innovation and Technology. 180 p. URL: http://www.inovativnost.net/materiali/clanki//nnovationManagement.pdf

[10] National Policy Board for Educational Administration (2015). Professional Standards for Educational Leaders. Reston, VA: Author. URL:http://education.vermont.gov/sites/aoe/files/documents/edu-vsbpe-item-4a-021617.pdf

[11] Porter-O'Grady T., Malloch K. (2010). Innovation Leadership: Creating the Landscape of Healthcare. Sudbury, MA: Jones and Bartlett Publishers. $384 \mathrm{p}$.

[12] Roscorla T. (2010). The 7 Steps to Innovative Leadership. URL: http:// www.convergemag.com/policy/The-7-Elements-ofInnovative-Leadership.html

[13] Shalley C.E., Perry-Smith J.E. (2001), "Perry-Smith Effects of social-psychological factors on creative performance: the role of informational and controlling expected evaluation and modelling experience", Organisational Behaviour and Human Decision Processes, Vol. 84, pp. 1-22

[14] Sullivan C. and Harper G. (eds) (2009) Authors at Work: The Creative Environment. Cambridge: Brewer. 192 p.

[15] Sundbo J. (1996), "The balancing of empowerment: a strategic resource based model of organizing innovation activities in service and low-tech firms", Technovation. 16. 8. PP. 397-409.

\section{References}

[1] Adjei D. (2013). Innovation Leadership Management. International Journal of ICT and Management. 1(2). 103-106/

[2] Adkins E. The Effectiveness of Principal Preparation Program Type for Administrative Work. Theses, Dissertations and Capstones. Paper 4. - 2009. URL:http://mds.marshall.edu/etd/4/

[3] Council of Chief State School Officers. Educational Leadership Policy Standards: ISLLC Washington, 2008 http://www.ccsso.org/Documents/2008/educational_Leadership_Policy_Standards_2008.pdf

[4] Davis S., Darling-Hammond L., LaPointe M., \& Meyerson D. (2005). School Leadership Study Developing Successful Principals. Stanford : Stanford Educational Leadership Institute.

[5] Gangwar S., Padmaja K .V. (2012). Building a Culture of Creativity and Practice of Innovation. HRD Practices in Contemporary Industries. Global Vision Publishing House. P. 93-102.

[6] Horth D. M., Vehar J. (2012). Becoming a Leader Who Fosters Innovation. Center for Creative Leadership. URL: http://www.ccl.org/wp-content/uploads/2014/03/BecomingLeaderFostersInnovation.pdf

[7] Integration of an Innovation Culture as Part of the Institutional Strategy: Strategic Guide for Higher Education Institutions. URL: http://www.medinnoall.eu/sites/medinnoall.eu/files/English.pdf.

[8] Jaussi K.S. and Dionne S.D. (2003). Leading for creativity: the role of unconventional leader behavior, Leadership Quarterly. 14. 4-5. PP. 475-98.

[9] Likar B., Fatur P., Mrgole U. (2013). Innovation management. 1 st. ed. Ljubljana: Korona plus - Institute for Innovation and Technology. 180 p. URL: http://www.inovativnost.net/materiali/clanki//nnovationManagement.pdf 
[10] National Policy Board for Educational Administration (2015). Professional Standards for Educational Leaders. Reston, VA: Author. URL:http://education.vermont.gov/sites/aoe/files/documents/edu-vsbpe-item-4a-021617.pdf

[11] Porter-O'Grady T., Malloch K. (2010). Innovation Leadership: Creating the Landscape of Healthcare. Sudbury, MA: Jones and Bartlett Publishers. $384 \mathrm{p}$.

[12] Roscorla T. (2010). The 7 Steps to Innovative Leadership. URL: http:// www.convergemag.com/policy/The-7-Elements-ofInnovative-Leadership.html

[13] Shalley C.E., Perry-Smith J.E. (2001), "Perry-Smith Effects of social-psychological factors on creative performance: the role of informational and controlling expected evaluation and modelling experience", Organisational Behaviour and Human Decision Processes, Vol. 84, pp. 1-22

[14] Sullivan C. and Harper G. (eds) (2009) Authors at Work: The Creative Environment. Cambridge: Brewer. 192 p.

[15] Sundbo J. (1996), "The balancing of empowerment: a strategic resource based model of organizing innovation activities in service and low-tech firms", Technovation. 16. 8. PP. 397-409.

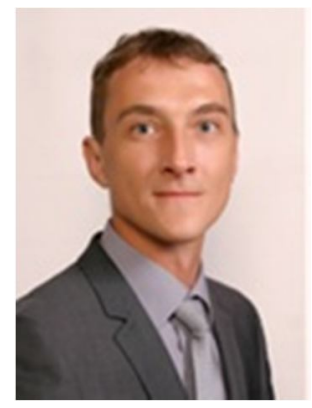

Козлов Дмитро Олександрович.

Кандидат педагогічних наук, доцент кафеедри менеджменту освіти та педагогіки вищої школи, Сумський державний педагогічний університет імені А. С. Макаренка,

вул. Роменська, 87, м. Суми, Україна, 40002.

Тел. 095-61-097-28. E-mail: 32012anna@gmail.com

Kozlov Dmytro Oleksandrovych.

Candidate of Pedagogical Sciences, Associate Professor of

Management of Education and Higher Education Pedagogy Department,

Sumy State Pedagogical University named after A. S. Makarenko,

St. Romenskaya, 87, Sumy, Ukraine, 40002.

Phone: 095-61-097-28. E-mail: 32012anna@gmail.com

ORCID: 0000-0003-1875-0726

\section{Citation (APA):}

Kozlov, D. (2019). Development of innovative culture of the head of educational establishment: foreign experience analysis.

Engineering and Educational Technologies, 7 (2), 59-69. doi: https://doi.org/10.30929/2307-9770.2019.07.02.06

\section{Цитування (ДСТУ 8302:2015):}

Козлов Д. О. Розвиток інноваційної культури керівника закладу освіти: аналіз зарубіжного досвіду / Інженерні та освітні технологіï. 2019. Т. 7. № 2. С. 59-69. doi: https://doi.org/10.30929/2307-9770.2019.07.02.06

Обсяг статmі: сторінок-11; умовних друк. аркушів - 1,593. 